University of Nebraska - Lincoln

DigitalCommons@University of Nebraska - Lincoln

April 1968

\title{
Can the Superior Learnability of Meaningful and Pleasant Words Be Transferred to Nonsense Syllables?*
}

\author{
Albert Silverstein \\ University of Rhode Island \\ Richard A. Dienstbier \\ University of Nebraska-Lincoln, rdienstbier2@unl.edu
}

Follow this and additional works at: https://digitalcommons.unl.edu/psychfacpub

Part of the Psychiatry and Psychology Commons

Silverstein, Albert and Dienstbier, Richard A., "Can the Superior Learnability of Meaningful and Pleasant Words Be Transferred to Nonsense Syllables?*" (1968). Faculty Publications, Department of Psychology. 218.

https://digitalcommons.unl.edu/psychfacpub/218

This Article is brought to you for free and open access by the Psychology, Department of at DigitalCommons@University of Nebraska - Lincoln. It has been accepted for inclusion in Faculty Publications, Department of Psychology by an authorized administrator of DigitalCommons@University of Nebraska - Lincoln. 
Published in Journal of Experimental Psychology 78:2 (1968), pp. 292-298. Copyright (C) 1968 American Psychological Association. Used by permission. "This article may not exactly replicate the final version published in the APA journal. It is not the copy of record." http://www.apa.org/journals/xge/

\title{
Can the Superior Learnability of Meaningful and Pleasant Words Be Transferred to Nonsense Syllables?*
}

\author{
Albert Silverstein and Richard A. Dienstbier
}

University of Rhode Island

\begin{abstract}
The $S \mathrm{~s}$ in 2 experiments first learned a PA list of words as responses to nonsense syllables. In 1 condition the words differed in meaningfulness (M) and in the other condition the words differed in pleasantness (PL). Next, $S$ s learned a 2nd PA list of the same syllables as responses to numbers. High-M words were learned faster than low-M words, but did not transfer either this difference in learning or the difference in rated $\mathrm{M}$ to the syllables. Pleasant words were learned faster than indifferent words in one experiment (men's) but not in the other (women's). In neither experiment did the words transfer their difference in learning to the syllables, but in the men's experiment they did transfer the difference in rated PL.
\end{abstract}

While both meaningfulness (M) and pleasantness (PL) of learning materials have received much attention from psychologists investigating verbal learning, it is not known whether or not different values of these variables can be transferred to new items in such a way as to alter their ability to be learned. Yet, such information is needed to determine the exact locus of these variables' influence on learning. Those theories of meaningfulness that emphasize the availability and integration of identifying responses to verbal items (cf. Goss \& Nodine, 1965; Underwood \& Schulz, 1960) would predict no effect of induced $\mathrm{M}$ on learning beyond that produced by familiarization. On the other hand, a theory of $\mathrm{M}$ that emphasizes the variety or distinctiveness of associative responses to an item (cf. Noble, 1963) would predict a gain in rate of learning as a direct function of the number of different new responses conditioned to items. Experiments by Bailey and Jeffrey (1958) and Parker and Noble (1963) have failed to reveal any difference in rate of PA learning for response terms conditioned to varying numbers of new associates beyond what could be ascribed to the influence of familiarization. An alternative approach to inducing $\mathrm{M}$ would be to condition single words of widely different $\mathrm{M}$ to nonsense syllables of initially equal and low M. Any theory proposing that $\mathrm{M}$ involves some dimension of a unitary response to a stimulus rather than a pattern of evoked responses (e.g., intensity of $r_{m}$, Osgood, Suci, \& Tannenbaum, 1957) would predict that such a conditioning of $M$ will transfer the difference in the ability to be learned from words to syllables. The current study employs such a conditioning procedure.

Recently, Staats (1964) has suggested that PL is an attribute of a meaning response that can be conditioned to neutral items, giving them secondary reinforcing properties. If so, such conditioning should lead to superior learning of items in direct proportion to the PL of words to

\footnotetext{
* This research was supported by United States Public Health Service Grant MH 08974 from the National Institute of Mental Health.
} 
which they were conditioned. Silverstein and McCreary (1964) produced evidence of a positive relation between induced PL and learning, but they used photographs of real scenes, rather than words, as conditioners of PL.

The present study reports two experiments in which $S$ s first learned a list of paired associates with nonsense syllables as stimuli and nouns as responses and then learned a second PA list using the same syllables as responses to two-digit numbers. In both experiments there was one condition in which the nouns differed in $\mathrm{M}$ and another in which they differed in PL. The major experimental question was whether the syllables in List 2 would be learned at different rates according to the $\mathrm{M}$ or PL of the words with which they had been paired.

\section{Method}

Experiments I and II were identical in methodology except the former used women $S$ s and words previously scaled by women for M and PL, while the latter used men $S \mathrm{~s}$ and words previously scaled by men. The experiments conformed to the A-B, C-A transfer design with the effects of the independent variables assessed within $S$ s through a mixed-list procedure. In the $\mathrm{M}$ condition half the nouns were high $\mathrm{M}$ and half were low $\mathrm{M}$; in the PL condition half the nouns were highly pleasant $(\mathrm{P})$ and half were indifferent (I). The A-B, C-A design was used because of the larger effects of both $\mathrm{M}$ (Underwood \& Schulz, 1960) and PL (Anisfeld \& Lambert, 1966) on responses than on stimuli, because conditioned meaning should be more potent when the CS is presented prior to the US (Staats, 1964), and because this design should yield less negative transfer than the A-B, A-C design.

Subjects.-In Exp. I there were 48 women $S$ s from basic psychology courses at the University of Rhode Island. For Exp. II Ss were 32 male undergraduates from basic psychology classes at the University of Rhode Island. All Ss were experimentally naive and were equally and randomly assigned to the two conditions. They were run individually by the anticipation method.
Stimulus materials.-The response words in List 1 were selected from a pool of 153 twosyllable nouns previously rated for PL and M by two independent samples of men and two samples of women students. A total of 101 of these nouns were common to the men's and women's lists (Silverstein \& Dienstbier, in press). The ratings of $\mathrm{M}$ were obtained through procedures like Noble's (Noble \& Parker, 1960), using a 5-point scale with a low of 1 and a maximum of 5 . The PL ratings were made on a 7-point scale running from very unpleasant (1) to very pleasant (7), with 4 as neutral. In the M condition PL of the sublists was equated, while printed frequency covaried with M (Thorndike \& Lorge, 1944). In the PL condition M of the sublists was equated and frequency was roughly equated. Table 1 shows the words used in the two experiments along with their PL and M ratings and Lorge (L) frequency counts. The values given a word in a list are those produced by the appropriate-sex sample.

The eight nonsense syllables used were taken from the $47 \%$ and $53 \%$ association values of Glaze (1928). Intralist similarity was low, with four different vowels and 14 different consonants used. No first or last letters were repeated in the list. The two-digit numbers used were of low-association value, from .79 to 1.22 (Battig \& Spera, 1962). No first or second digits were repeated, fives and zeros were not used, and no number was the reverse of any other number.

In each experiment two different pairings of stimuli and responses were used for both lists, and half the $S \mathrm{~s}$ in each condition were assigned to a pairing. The pairings were randomly determined with the following restrictions: In List 1 each syllable was paired with a word from a different sublist in the two pairings, and no syllable was paired with a word that began with its first letter. In List 2 each number was paired once with a syllable from each sublist (as determined by the word it had been paired with previously), and no number was paired with a syllable beginning with its first phoneme. There were four different random orders of presentation used for the pairs of both List 1 and List 2. Starting orders were randomly assigned to $S \mathrm{~s}$.

Apparatus.-Stimuli were mounted on 35mm. slides and shown by a Kodak Carousel automatic slide projector. The automatic timer of the projector was set at $5 \mathrm{sec}$. per slide with $10 \mathrm{sec}$. between trials. 
TABLE 1

WORDS USED IN LIST 1

\begin{tabular}{|c|c|c|c|c|c|c|c|}
\hline \multirow{2}{*}{ Words } & \multicolumn{3}{|c|}{ Exp. I (Women) } & \multirow{2}{*}{ Words } & \multicolumn{3}{|c|}{ Exp. II (Men) } \\
\hline & $\mathbf{M}$ & PL & $\mathbf{L}$ & & $\mathbf{M}$ & $\mathbf{P L}$ & L \\
\hline \multicolumn{8}{|c|}{ Pleasantness Condition } \\
\hline $\begin{array}{l}\text { P Words } \\
\text { Caress } \\
\text { Delight } \\
\text { Kindness } \\
\text { Sunshine } \\
M\end{array}$ & $\begin{array}{l}3.71 \\
3.73 \\
3.71 \\
3.93 \\
3.77\end{array}$ & $\begin{array}{l}6.30 \\
6.34 \\
6.37 \\
6.41 \\
6.36\end{array}$ & $\begin{array}{r}75 \\
353 \\
115 \\
194 \\
184\end{array}$ & $\begin{array}{l}\text { P Words } \\
\text { Caress } \\
\text { Laughter } \\
\text { Pleasure } \\
\text { Summer } \\
M\end{array}$ & $\begin{array}{l}3.54 \\
3.73 \\
4.10 \\
4.46 \\
3.86\end{array}$ & $\begin{array}{l}6.34 \\
6.24 \\
6.43 \\
6.30 \\
6.33\end{array}$ & $\begin{array}{l}75 \\
275 \\
442 \\
783 \\
393.8\end{array}$ \\
\hline I Words & & & & I Words & & & \\
\hline $\begin{array}{l}\text { Breakfast } \\
\text { Grocer } \\
\text { Object } \\
\text { Paper } \\
\quad M\end{array}$ & $\begin{array}{l}3.41 \\
3.19 \\
3.33 \\
3.40 \\
3.33\end{array}$ & $\begin{array}{l}3.38 \\
4.17 \\
3.85 \\
4.03 \\
3.86\end{array}$ & $\begin{array}{c}539 \\
31 \\
394 \\
1235 \\
549.8\end{array}$ & $\begin{array}{l}\text { City } \\
\text { Highway } \\
\text { Paper } \\
\text { Table } \\
M\end{array}$ & $\begin{array}{l}4.39 \\
3.87 \\
3.81 \\
3.57 \\
3.91\end{array}$ & $\begin{array}{l}4.46 \\
4.29 \\
4.06 \\
4.04 \\
4.21\end{array}$ & $\begin{array}{c}1258 \\
156 \\
1235 \\
1325 \\
993.5\end{array}$ \\
\hline \multicolumn{8}{|c|}{ Meaningfulness Condition } \\
\hline $\begin{array}{l}\text { High-M Words } \\
\text { City } \\
\text { Morning } \\
\text { Study } \\
\text { Woman } \\
M\end{array}$ & $\begin{array}{l}4.36 \\
3.74 \\
3.98 \\
4.29 \\
4.07\end{array}$ & $\begin{array}{l}3.74 \\
5.22 \\
3.57 \\
5.20 \\
4.63\end{array}$ & $\begin{array}{r}1258 \\
2015 \\
942 \\
2431 \\
1661\end{array}$ & $\begin{array}{l}\text { High-M Words } \\
\text { Building } \\
\text { Highway } \\
\text { Paper } \\
\text { Story } \\
M\end{array}$ & $\begin{array}{l}4.03 \\
3.87 \\
3.81 \\
3.81 \\
3.88\end{array}$ & $\begin{array}{l}3.39 \\
4.29 \\
4.06 \\
4.93 \\
4.17\end{array}$ & $\begin{array}{r}1014 \\
156 \\
1235 \\
1651 \\
1014\end{array}$ \\
\hline Low-M Words & & & & Low-M Words & & & \\
\hline $\begin{array}{l}\text { Arbor } \\
\text { Boulder } \\
\text { Mallet } \\
\text { Zenith } \\
\quad M\end{array}$ & $\begin{array}{l}2.20 \\
2.37 \\
2.21 \\
2.40 \\
2.29\end{array}$ & $\begin{array}{l}4.73 \\
5.07 \\
3.36 \\
4.87 \\
4.51\end{array}$ & $\begin{array}{c}29 \\
13 \\
17 \\
2 \\
15.3\end{array}$ & $\begin{array}{l}\text { Arbor } \\
\text { Dotage } \\
\text { Lorry } \\
\text { Sequel } \\
\quad M\end{array}$ & $\begin{array}{l}2.25 \\
1.44 \\
1.74 \\
2.10 \\
1.88\end{array}$ & $\begin{array}{l}4.53 \\
3.57 \\
4.27 \\
3.97 \\
4.09\end{array}$ & $\begin{array}{r}29 \\
1 \\
3 \\
3 \\
9\end{array}$ \\
\hline
\end{tabular}

Procedure.-For the pairs in both List 1 and List 2 the stimulus term appeared for $5 \mathrm{sec}$. followed by a 5 -sec showing of its paired response. With List $1 S$ s were instructed to spell the nonsense syllables and pronounce the words out loud on the study trial, but, thereafter, they were to try to anticipate the words only. The $S$ s were run to a criterion of two successive errorless trials in order to maximize the degree of conditioning. Those who failed to reach criterion within the limit of 17 trials were replaced in the design. With list $2 \mathrm{Ss}$ were instructed that the syllables would be the same as those they had previously encountered and to both say the number and spell the syllable out loud on the study trial. Thereafter, they were to try to anticipate the syllables only. This task was continued to a criterion of one perfect trial or a minimum of 10 trials. Any $S$ who failed to anticipate each pair correctly at least once within the limit of 20 trials was replaced in the design. After learning List $2 \mathrm{Ss}$ were asked to rate the nonsense syllables on the dimension appropriate to their experimental condition. In the PL condition $S \mathrm{~s}$ were given a thermometer-type scale on a card for rating syllables' PL. This was a 7-point scale like that used for the word ratings. In the $\mathrm{M}$ conditions $S \mathrm{~s}$ were given a Noble-type scale (Noble, 1961) ranging from "no associations" (1) to "very many associations" (5). 
Noble's instructions were used for this task. The syllables were shown to $S \mathrm{~s}$, one at a time, for as long as was needed for the ratings.

\section{Results}

In reading the presentation of results it should be remembered that the sex of $S \mathrm{~s}$ is confounded with different response terms in the first list, but not in the second list in which all $S$ s learned the same items. All statistical tests made on percentages followed transformation of the data to arcsines. The degrees of freedom associated with tests made of Exp. I were 47 and for Exp. II were 31.

Meaningfulness: List 1.- The mean number of trials to the criterion of two perfect trials was 10.43 for the women and 14.00 for the men. As can be seen from Table 2 both experiments showed the typical substantial advantage for highM over low-M words. Both the women's and men's differences were reliable beyond .001 ( $t=7.62$ and 4.48 , respectively) .In both experiments this advantage was reflected in the response-availability stage (Under wood \& Schulz, 1960). The women completed this stage more rapidly for the high-M words by .61 trials ( $t$ $=3.11, p<.01)$ and the men by .88 trials $(t=3.15, p<.01)$. While the women continued to show the superiority of the high-M words through the association stage (Underwood \& Schulz, 1960) by .74 trials $(t=3.52, p<.01)$, the men completed this stage with nearly identical speeds for the two sublists. The percentage correct following first correct response, a measure of associative stability, was reliably greater for high-M words in both experiments (by 12.9\% for the women and $7.3 \%$ for the men).

Meaningfulness: Transfer.-The speed of learning List 2 was virtually identical for women and men $S$ s (11.9 and 12.5 trials). Table 2 shows that the number of correct anticipations over 10 trials was quite similar for the syllables paired with highly meaningful words (high $\mathrm{M}$ ) and those paired with low meaningful words (low $\mathrm{M})$ in both experiments. In neither case was the $t$ for the difference reliable. Stage

TABLE 2

Major Statistics: Means and Difference- $t$ 's

\begin{tabular}{|c|c|c|c|c|c|c|}
\hline & \multicolumn{3}{|c|}{ Exp. I (Women) } & \multicolumn{3}{|c|}{ Exp. II (Men) } \\
\hline \multicolumn{7}{|c|}{ Meaningfulness Condition } \\
\hline Statistic & $\begin{array}{c}\text { High-M } \\
\text { Mean }\end{array}$ & $\begin{array}{l}\text { Low-M } \\
\text { Mean }\end{array}$ & $t_{\text {ditt }}$ & $\underset{\text { Mean }}{\text { High-M }}$ & $\begin{array}{l}\text { Low-M } \\
\text { Mean }\end{array}$ & $t_{\text {diff }}$ \\
\hline $\begin{array}{l}\% \text { Correct List } 1 \\
\text { No. Correct List } 2 \\
\text { Syllable M }\end{array}$ & $\begin{array}{l}78.3 \\
21.0 \\
1.66\end{array}$ & $\begin{array}{l}58.5 \\
18.7 \\
1.67\end{array}$ & $\begin{array}{l}7.62^{*} \\
1.79 \\
<1\end{array}$ & $\begin{array}{l}64.5 \\
17.7 \\
1.89\end{array}$ & $\begin{array}{l}54.1 \\
18.4 \\
1.59\end{array}$ & $\begin{array}{l}4.48^{*} \\
<1 \\
1.43\end{array}$ \\
\hline \multicolumn{7}{|c|}{ Pleasantness Condition } \\
\hline & P Mean & I Mean & tiint & P Mean & I Mean & tdift \\
\hline $\begin{array}{l}\text { \% Correct List } 1 \\
\text { No. Correct List } 2 \\
\text { Syllable PL }\end{array}$ & $\begin{array}{l}62.4 \\
19.7 \\
4.61\end{array}$ & $\begin{array}{c}63.8 \\
19.2 \\
4.32\end{array}$ & $\begin{array}{l}<1 \\
<1 \\
1.69\end{array}$ & $\begin{array}{c}68.5 \\
18.0 \\
4.95\end{array}$ & $\begin{array}{c}56.8 \\
16.8 \\
4.02\end{array}$ & $\begin{array}{l}3.76^{*} \\
<1 \\
2.98^{*}\end{array}$ \\
\hline
\end{tabular}

$\bullet<.01$. 
analyses revealed no differences between the two sublists of either experiment for the response-availability stage, but showed a small superiority for the high-M sublists in the association stage. This superiority was .26 trials for the women $(t=1.51, p<$ $.15)$ and .84 trials for the men $(t=1.75, p$ $<.10)$. By pooling the scores on this stage of learning for both experiments a mean difference of .49 trials appeared, which is reliable at $.05(t=2.23)$.

The percentages of correct response following first correct response were nearly identical for the two sublists of both experiments. There also were no reliable differences for intralist error rates for the two sublists. Table 2 also shows the near identity of meaningfulness ratings for the syllables paired with high-and low-M words. In neither experiment did the difference approach reliability.

Pleasantness: List 1.- The mean number of trials to criterion was 11.51 for the women and 12.25 for the men. Table 2 shows that the $\mathrm{P}$ words were learned more rapidly than the I words by the men in Exp. II, but that PL had no effect on the women in Exp. I. For the men the difference was very reliable $(t=3.76, p<.01)$ , and manifested itself in faster responseavailability (by .63 trials) and association (by .55 trials) stages, and in a greater percentage correct following first correct response (by $7.50 ; 0$ ). However, only the response-availability difference was reliable $(t=2.14, p<.05)$. The values of $t$ for the other two differences failed to reach $10 \%$ significance. For the women's experiment none of these differences between $\mathrm{P}$ and I words produced a $t$ greater than unity.

Pleasantness: Transfer.-The speed of learning List 2 to criterion was 10.66 trials for the women and 13.69 trials for the men. Table 2 shows that there was no reliable difference in number correct over
10 trials between the $\mathrm{P}$ and I syllables (in terms of the words they had been paired with) for either experiment. In line with this result, the differences between sublists in both experiments were virtually nil for the response-availability and association stages and for the percentage correct following first correct response. Nor were there reliable differences between sublists in intralist error rates, for either experiment. The differential PL of the two sublists of words was transferred reliably to the syllables in the men's experiment $(t=$ $2.98, p<.01)$, but not in the women's experiment $(t=1.69, p>.10)$.

\section{Discussion}

The evidence from these experiments is that, while high-M words were learned faster than low-M words and (in some circumstances) $\mathrm{P}$ words were learned faster than I words, these differential learnabilities were not transferred to nonsense syllables associated with those words. In the meaningfulness case the only difference found between syllables that had been differentially conditioned was in the speed with which responses were attached to correct stimuli after becoming available. The most probable explanation for this small effect is that the words with which the syllables had been associated in List 1 sometimes served as mediators in List 2 between the syllables and the numbers, and that the high-M words were better able to serve this function. Such an explanation is based on the well-documented formation of backward associations during PA learning (cf. Feldman \& Underwood, 1957). An explanation of this effect in terms of syllables paired with high-M words acquiring a wider range of new associations is implausible in view of the absence of a difference in rated $\mathrm{M}$ 
between the two sublists. The absence of any difference in speed of response learning between the two sublists indicates that none of the differences in strength of identifying responses were transferred from words to syllables, and supports the contention of Goss and Nodine (1965, p. 227) that the only facilitation in learning that can be produced by inducing meaning or meaningfulness arises from greater integration and availability of recognition responses to items on the list.

While there is good reason for our belief that the A-B, C-A paradigm maximized the likelihood of obtaining an effect of induced $\mathrm{M}$, only further research can rule out the possibility that an effect could be produced by some other paradigm (e.g., the A-B, C-B backward conditioning paradigm). Meanwhile, our failure to produce any differences in the overall course of learning the syllables by inducing $\mathrm{M}$ suggests that the traditional superiority of high-M over low-M words in learning is not the result of differences in any dimension of a unitary meaning response such as that measured by Polarity on the Semantic Differential (Osgood et al., 1957).

The failure to obtain any effect of induced PL on learning, even in Exp. II where $\mathrm{P}$ words were more quickly learned than I words, stands at variance with the findings of Silverstein and McCreary (1964) and Silverstein (1966). These latter studies differed from the current one only in that they used photographs of real scenes as conditioning stimuli. The most obvious resolution of these findings is the hypothesis that pleasant words are substantially less potent than photographs in eliciting emotional reactions and, hence, less capable of producing conditioning of the affect. It is not clear what the basis was for the judgments of higher PL obtained for P-paired than for I-paired sylla- bles. It may have been the result of $S$ s recalling the specific words associated with the syllables and using them as the basis for a difficult judgment. In any event, these results point out the danger involved in using shifts in pleasantness ratings as an index of conditioned incentive value (cf. Staats, 1964).*

There is reason to believe that the absence of a difference in speed with which women $S$ s learned the P and I words was related to the presence of a higher level of task anxiety in women than in men Ss. Such anxiety may be presumed to interfere with any difference in affective response produced by $\mathrm{P}$ and I items. Preliminary evidence from our laboratory indicates that anxiety-reducing manipulations (e.g., incidental learning of List 1) can produce a superiority for P over I items with women $S$ s.

* While the conditioning procedure used by Staats was such that recall of specific emotional words was unlikely to be the basis for the shifts in ratings he reported, and they may reflect genuine affective conditioning, the methodological point regarding the use of rating data remains an important one.

\section{References}

ANISFELD, M., \& LAMBERT, W. E. When are pleasant words learned faster than unpleasant words? Journal of Verbal Learning and Verbal Behavior, 1966, 5, 132-141.

BAILEY, J. H., \& JEFFREY, W. E. Response strength and association value in stimulus predifferentiation. Psychological Reports, 1958, 4, 715-721.

BATTIG, W. F ., \& SPERA, A. J. Rated association values of numbers from $0-100$. Journal of Verbal Learning and Verbal Behavior, 1962, I, 200-202.

FELDMAN, S. M., \& UNDERWOOD, B. J. Stimulus recall following paired-associate verbal learning. Journal of Experimental Psychology, 1957, 53, 11-15. 
GLAZE, J. A. The association value of nonsense syllables. Journal of Genetic Psychology, 1928, 35, 255-269.

Goss, A. E., \& NODINE, C. F. Paired-associates learning: The role of meaningfulness, similarity, and familiarization. New York: Academic Press, 1965.

NOBLE, C. E. Measurements of association value (a), rated associations (a'), and scaled meaningfulness (m') for the $2100 \mathrm{CVC}$ combinations of the English alphabet. Psychological Reports, 1961, 8, 487-521.

NOBLE, C. E. Meaningfulness and familiarity. In C. N. Cofer \& B. S. Musgrave (Eds.), Verbal behavior and learning: Problems and processes. New York : McGraw-Hill, 1963.

NOBLE, C. E., \& PARKER, G. V. C. The Montana scale of meaningfulness. Psychological Reports, 1960, 7, 325-331.

OSGOOD, C. E., SUCI, G. J ., \& TANNENBAUM, P. H. The measurement of meaning. Urbana: University of Illinois Press, 1957.

PARKER, G. V. C., \& NOBLE, C. E. Experimentally produced meaningfulness $(\mathrm{m})$ in paired-associate learning. American Journal of Psychology, 1963, 76, 579-588.
SILVERSTEIN, A. Acquired word value and verbal learning and retention: Replication and extension. Psychological Reports, 1966, 18, 357-358.

SILVERSTEIN, A., \& DIENSTBIER, R. A. Rated meaningfulness and pleasantness of 101 English nouns. Journal of Verbal Learning and Verbal Behavior, in press.

SILVERSTEIN, A., \& McCREARY, C. Acquired word value and verbal learning. Psychological Reports, 1964, 14, 499-504.

STAATS, A. W. Conditioned stimuli, conditioned reinforcers, and word meaning. In A. W. Staats (Ed.), Human learning. New York: Holt, 1964.

THORNDIKE, E. L., \& LORGE, I. The teacher's word book of 30,000 words. New York: Teachers College, Columbia University, Bureau of Publications, 1944.

UNDERWOOD, B. J., \& SCHULZ, R. W. Meaningfulness and verbal learning. Philadelphia: Lippincott, 1960.

(Submitted September 1967) 